before it reached the floor of the House.

But Sensenbrenner now says its "up to secretary Peña" to meet his demands and get the money restored. The bill is expected to reach the House floor later this month. According to congressional staff and laboratory officials, supporters of the LHC are worried that an attempt to restore the funds on the floor of the House could well be defeated. "Everyone knows that if you take this to the floor, you lose," says one.

Sensenbrenner's staff say that he supports US participation in the LHC, but wants a better deal that will survive future attacks in Congress. "There are good deals and bad deals - Martha Krebs' deal is a bad one that has to be changed," Sensenbrenner says.

Nevertheless, his recent public statements have been short on praise for the LHC, and have reflected some of the views of Joe Barton (Republican, Texas) the project's fiercest congressional critic (see Nature 386, 97; 1997).

Sensenbrenner told last week's AAAS meeting that, while he was "all for" international collaboration in science, the Superconducting Super Collider (SSC) had failed because it had not attracted international contributions, particularly from Europe.

"Carlo Rubbia, the [then] director of CERN, waved his finger at the United States and actively lobbied against European support for SSC," Sensenbrenner argued. A European pledge to help with a future US machine would "put an end to Rubbia-ism in Geneva", he suggested.

Whatever happens next, Sensenbrenner's attack on the initial deal between the DoE and CERN marks the unravelling of the Clinton administration's strategy of pushing through, with minimal fuss, the largest-ever US investment in an overseas science project. Costs would involve $\$ 450$ million from the DoE and probably another $\$ 80$ million from the National Science Foundation.

Three years ago, a panel chaired by Sidney Drell, deputy director of the Stanford Linear Accelerator Center in California, suggested that the United States should participate in the project. But it warned that it would need the explicit endorsement of President Clinton to succeed (see Nature 369, 266; 1994).

Since then, however, Krebs' Office of Energy Research has pursued the agreement on its own, with little public backing from Hazel O'Leary, the former energy secretary, or other senior members of the administration. Last week, the new energy secretary sought to correct this, speaking out in favour of the project at the AAAS meeting.

"We are requesting funds to participate in the construction of the next major high energy physics research facility in the world the LHC," Peña said. "Successful international collaboration is important to the future of these large scientific facilities; we must succeed on this one."

ColinMacilwain

\title{
Spaceflight monkey's death 'raises new safety issues'
}

[WASHINGTON] US space researchers have dropped plans to fly rhesus monkeys on the Russian Bion 12 spacecraft next year. Their decision follows the conclusions of a review panel that the animals face a previously unsuspected risk of death on their return to Earth.

The panel was set up after one of the two monkeys that were used on the 14-day Bion 11 mission last December died unexpectedly under anaesthesia during a routine biopsy conducted the day after landing (see Nature 385, 289;1997). The mission was one of a series designed to test the effects of weightlessness and space radiation on living organisms.

The decision brings to an abrupt end a long-running controversy about whether the National Aeronautics and Space Administration (NASA) should fly monkeys on the Bion missions. The December mission, for which NASA had followed the advice of several scientific review panels, had encountered protests from animal rights groups. There have also been attempts to kill the programme in Congress. Indeed, Tim Roemer (Democrat, Indiana), a member of the House of Representatives Science committee, had begun circulating a "Dear Colleague" letter headlined "Get the monkey off the taxpayer's back!", the day before NASA's decision.

Alice Hellerstein, a spokeswoman for the American Physiological Society, which had backed the Bion experiments during congressional debates last year, says " $[t]$ he timing is unfortunate, because it looks like they were pressured politically". However, she believes that, despite the possible embarrassment to NASA, the agency made a "tough but honest" decision based on new scientific evidence.

Ronald Merrell, chairman of Yale University's department of surgery and head of the panel that reviewed the Bion research protocols both before and after the flight, says that as well as being a genuine surprise, the result is of considerable scientific interest.

Russian researchers had previously conducted 10 successful biopsies on monkeys after long space-flights, following procedures used routinely in laboratories on Earth. But they had never anaesthetized an animal so soon after its return from space.

According to NASA's chief veterinarian, Joseph Bielitzki, the soonest it had been done previously was seven days after landing. But the Bion 11 experiment required that tissue be taken immediately from the monkeys in order to investigate the body's transition from weightlessness to gravity.
Merrell says that physiological changes that occur in space appear to have reduced the monkey's ability to tolerate the stress of anaesthesia. The review panel therefore concluded that continuing with the same experimental protocol for Bion 12 posed an additional risk to the test subjects.

The panel did not tell NASA to scrap the project, says Merrell. But, in the light of the new findings, the agency faced a choice between risking the death of the Bion 12 monkeys - which would have inflamed political opponents - or waiting several days after landing before taking biopsy tissue, which would reduce its value.

NASA headquarters chose to cut its losses after what Bielitzki describes as "a lot of discussion", reaching as high as Daniel Goldin, NASA's administrator. According to Bielitz$\mathrm{ki}$, there is "a significant amount of disappointment" among Bion 12 researchers.

The rhesus monkeys were originally to have flown on a US Spacelab mission last year, but were switched to Bion when that flight was cancelled. The experiment had been approved by four scientific review panels since 1988, including one convened by the American Institute of Biological Sciences. But the plan to anaesthetize the monkeys immediately after landing never emerged as a significant worry. "Hindsight is always 20-20," says Bielitzki.

Other US animal experiments will still fly on Bion 12, along with investigations sponsored by Russian and French researchers. And, ironically, the death of the Bion 11 monkey may leave an important scientific legacy. NASA may want to reconsider whether or not to operate immediately on astronauts who return from space in an emergency. "[Agency doctors] are probably thinking about this right now," says Merrell.

Tony Reichhardt



THE THREE WISE NASA OFFICIALS 